\title{
Making London, through other cities
}

\author{
Jennifer Robinson
}

The future of any city is made and imagined in a world of cities - in a world with competitor cities, cities which could be adopted as models, or cities that might perform a future to be vigorously avoided. Cities are very often placed imaginatively alongside one another as we dream urban futures. Boris Johnson, Mayor of London in 2012, entrained the world of cities in his personal vision that London would be the 'best big city in the world' (Greater London Authority, 2011). The competitor cities of New York, Frankfurt and Tokyo loomed large as the detailed London plan articulated the potential for supporting strategic elements of London's economy. And the dynamism of Asia's urban skylines arguably stretched London's horizons upward as the previous Mayor responded to the sense of a fading urban image by changing planning regulations to allow tall buildings (McNeill, 2002) - the geopolitics of huge buildings is just one of the ways in which China is announcing its global ascendance. But Ken Livingstone's mayoralty also saw the creation of a co-operative network of large cities (the C40) committed to seeking creative solutions to the challenges of climate change (Gavron, 2007).

The prolific entwining of cities with each other will be a crucial determinant of London 2062. However, as these examples show, there are many different ways to approach such planetary entanglement. In the 2012 debates about London's airport capacity, competition and collaboration, real choices for the future were framed - should the city urgently extend airport capacity or lose traffic (and by implication economic growth) to other hub airports more able and willing to expand? Or perhaps could the intense connections amongst European cities be used to provoke a more interdependent solution, one where air traffic is shared across the continent and ground travel plays a bigger role? For geographer Doreen Massey London's prolific connections with many other parts of the world come together in the spaces of the city and interweave and overlap to shape the city's possible futures (Massey, 2007); they also expose the political choices we have for shaping London's future, and future co-existence on this planet. Her analysis resonated strongly with Mayor Livingstone's controversial negotiations with the Venezuelan government of Chavez for cheaper petrol prices for London buses - the affordable travel option which expanded considerably in his term. An unusual connection, perhaps, and one which was

How to cite this book chapter:

Robinson, J. 2013. Making London, through other cities. In: Bell, S and Paskins, J. (eds.) Imagining the Future City: London 2062. Pp. 23-26. London: Ubiquity Press. DOI: http://dx.doi.org/10.5334/bag.b 
derided and terminated by Ken's conservative successor, but it speaks of the great diversity of arcs and flows which tie the fortunes of cities around the world together, from Caracas to Cairo, Nanjing to Nairobi.

Such is the interconnectedness of the world of cities that many urbanists now insist we think about urbanisation beyond the physical entity of the city - Henri Lefebvre's hypothesis of the 'complete urbanisation of society' asks us to think of our social world as profoundly urban, made through social relations which extend across the globe and result in urban forms which often stretch beyond any physical limits we can identify. As 'the urban' generates a planetary social form, it is the social and physical processes of urbanisation rather than discrete cities which should attract our attention (Lefebvre, 2003; Brenner \& Schmid, 2012). According to many commentators, London's future will be made in a world of rapidly growing, extremely large and territorially extended cities - several cities now enumerate above 20 million, and London is likely to be a long way from being a 'big' city in 2062. It will probably be somewhat peripheral to the making of the planet's urban future.

Many other cities, then, are connected up in one way or another to the fortunes and lives of this city and its citizens. For London this worldliness is deeply embedded in the daily lives and dreams of its residents who have made their way to this city from so many different places, and whose livelihoods are closely imbricated with elsewhere. These interconnections are often seen as emblematic of the city as a whole: the city of Empire, the most multicultural city in the world, a centre of financial globalisation. The kinds of connections London forges with other places now matter for the future of the planet; they also make the future of this city. London 2062 will be made by political choices about how to engage with these wider connections, and how Londoners choose to cohabit in the midst of the many intersecting worlds of the city.

China Miéville, the novelist who writes London's future obliquely in his 'new weird' fantasy novels, comments that he is 'not interested in fantasy or SF as utopian blueprints, that's a disastrous idea. There's some kind of link in terms of alterity... If you think about the surrealists, the estrangement they were trying to create was a political act. There's some shared soup somewhere in my head from which these two things are ladling.' (Jordan, 2011) The estrangement which science fiction and fantasy novels effect as they take us from somewhere deeply familiar to a shocking alternative reality perform this politics of alterity - of imagining alternative, other Londons (Moylan, 2002). Miéville's award-winning novel (Pan Books, 2009) The City and the City takes us very quickly from a conventional detective scene to seek out (detect) the strange but achingly familiar truth of a city juxtaposed/superimposed on its other, whose buildings and inhabitants are routinely 'unseen' day by day as two coexistent and tightly imbricated realities are kept firmly apart.

This is a quintessentially London geography - the intricate mosaic of this city sees wealthy and poor, diverse ethnicities and many different language groups sharing streets, parks, festivals and often schools in an apparent outpouring of tolerance and multiculturalism. But this subtle proximity can also be seen to be managed through a measure of indifference and produces startlingly divergent outcomes in life chances, educational opportunities, housing quality and income - outcomes so differentiated that the parallel social worlds they invoke could come to resemble nothing less than the hard lines of segregation which appear so solid in some of the other cities which shadow this novel - Jerusalem, Johannesburg, Sarajevo. These divisions foreshadow South African novelist Lauren Beukes' equally astute but more clearly scifi Zoo City (Beukes, 2010) in which the segregation of today's Johannesburg reaches into a future defined by the abandonment of the city centre to second class criminalised citizens with companion animals assigned to soak up their dangerous psychological excesses.

Current trends, such as the corporate globalisation of London's physical spaces through eager regeneration, the displacement of working class communities and the decline of social housing stock are exacerbating the social inequalities of the city, creating a futuristic exclusion of the poor (Imrie et al., 2010) - a spatial inversion of the zoo city fantasy as the city centre is increasingly 
imagined as the preserve of the wealthy. 'Unseeing' (which might be figured as a kind of tolerance) and spatial segregation infect one another as political choices arguably describing a path towards a noir urban future.

The shock of Mièville's fantastic elaboration of the familiar practice of urban unseeing - reminiscent of Simmel's famous blasé attitude, or the discreet aversion of eyes familiar to anyone who catches the tube in London - juxtaposed with the extreme nihilism of Beukes' futuristic Johannesburg illuminates the political challenges of London 2062. The ways in which we choose to live together now, and the ways in which we practice the interconnections which make this city in the context of multiple elsewheres, will determine the future geography of this city, and shape the future of the world of cities.

\section{References}

Beukes L. 2010. Zoo City. Oxford: Angry Robot

Brenner N. and Schmid C. 2012. Planetary Urbanisation. In Gandy M., editor. Urban Constellations. Berlin: Jovis. p. 10-13

Gavron N. 2007. Towards a Carbon Neutral London. In Burdett R. and Sudjic D., editors. The Endless City. London: Phaidon. p. 372-385

Greater London Authority. 2011. The London Plan: Spatial Development Strategy for Greater London. London: Greater London Authority

Imrie R., Lees L. and Raco M. 2010. Regenerating London: Governance, Sustainability and Community in a Global City. London: Routledge

Jordan J. 2011. A Life in Writing: China Miéville. The Guardian. 14 May. Available from; http:// www.theguardian.com/books/2011/may/14/china-mieville-life-writing-genre. [Accessed 9 August 2013]

Lefebvre H. 2003. The Urban Revolution. Minneapolis: University of Minnesota Press

Massey D. 2007. World City. Cambridge: Polity Press

McNeill D. 2002. The mayor and the world city skyline: London's tall buildings debate. International Planning Studies. 7(4): 325-334

Moylan T. 2002. Scraps of the Untainted Sky: Science Fiction, Utopia, Dystopia. Boulder: Westview 


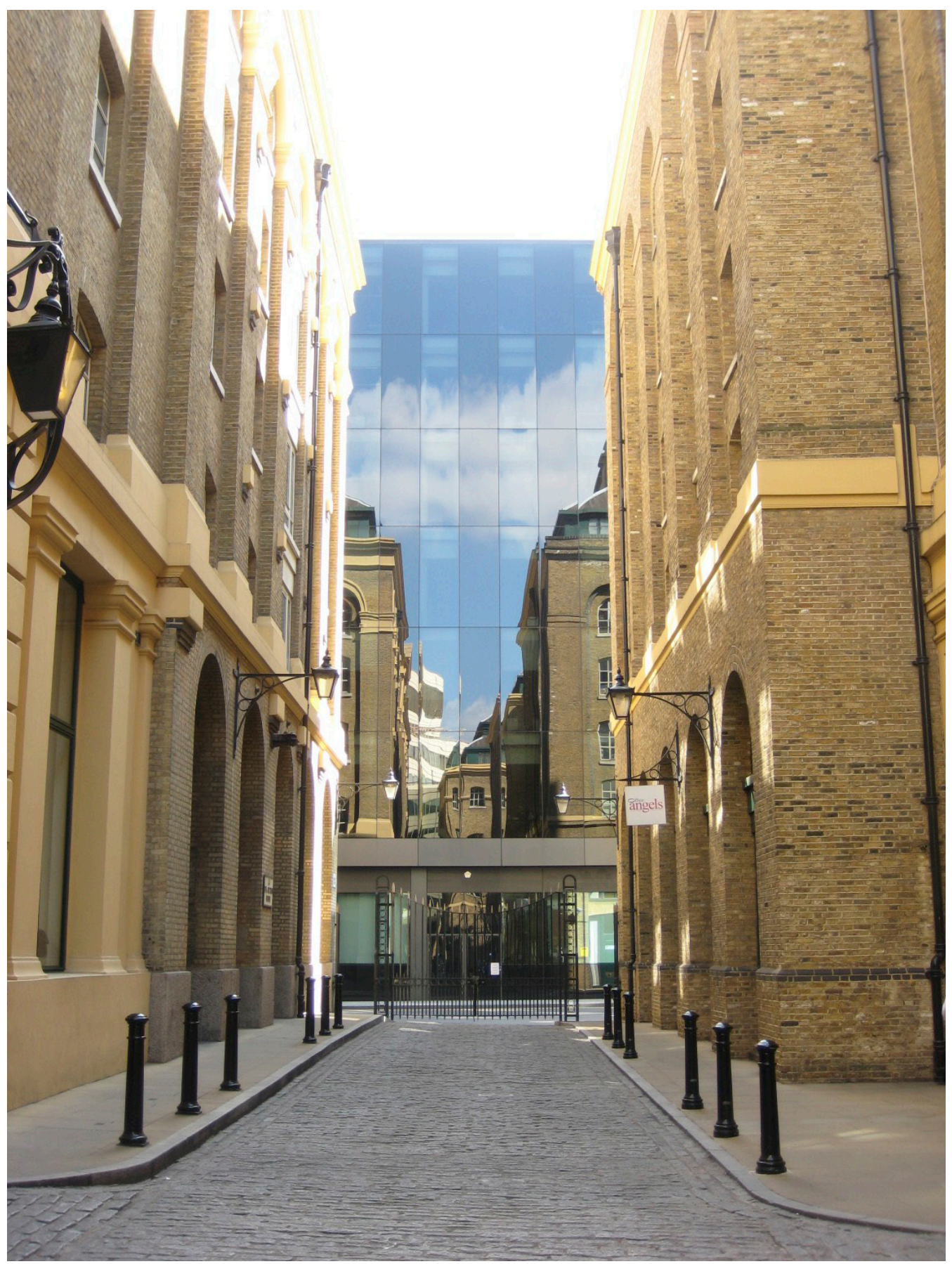

